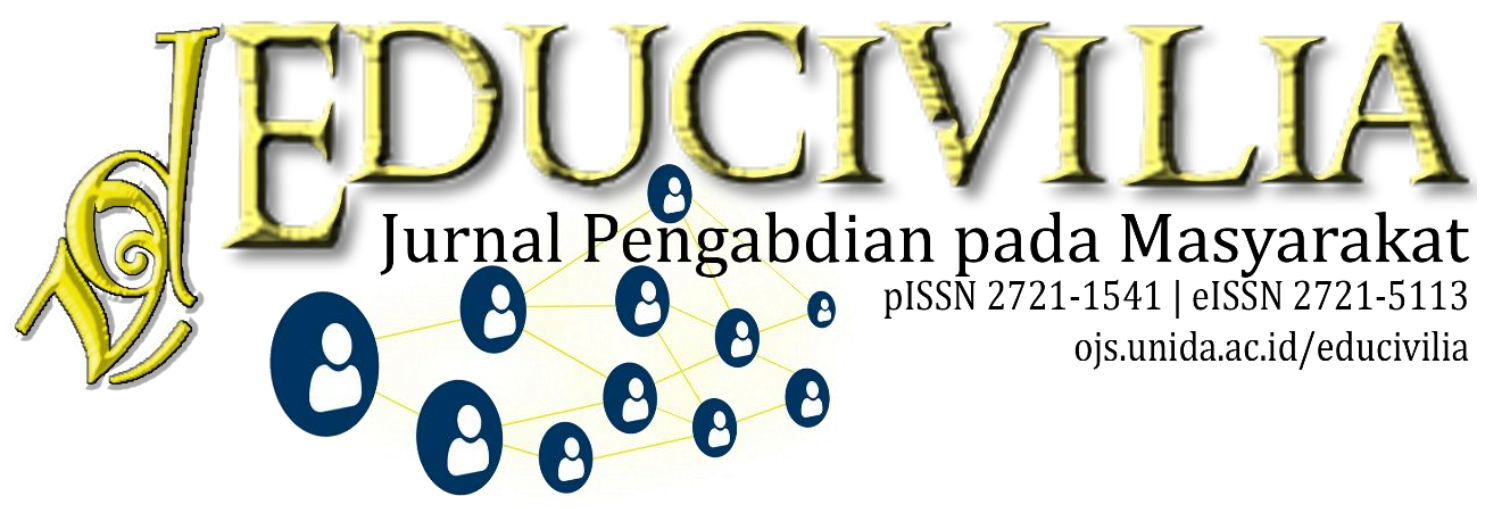

\title{
Pengembangan Literasi Demokrasi dalam Pemilihan Pemimpin melalui Proses Pembelajaran
}

\author{
Febriyantina Istiara ${ }^{1}$, Nuryansyah Adijaya², Dery Ciciria ${ }^{3}$ \\ 1,3 STKIP PGRI Bandar Lampung \\ 2Universitas Esa Unggul
}

Kilas Artikel

Volume 2 Nomor 1

Januari 2021: 63-71

DOI: $10.30997 /$ ejpm.v2i1.3165

Article History

Submission: 15-08-2020

Revised: 14-09-2020

Accepted: 19-01-2021

Published: 27-01-2021

Kata Kunci:

Demokrasi Siswa. Literasi

Sekolah, Pemilihan Pemimpin

Keywords:

Student Democracy. School

Literacy, Leader Selection

Korespondensi:

(Nuyansyah Adijaya)

(nuryansyah@esaunggul.ac.id)

\begin{tabular}{l} 
Abstrak \\
\hline Demokrasi adalah sebuah sistem pemerintahan dimana kekuasaan \\
tertinggi berada di tangan rakyat. Dunia pendidikan termasuk \\
sekolah memiliki peran penting dalam membantu memperbaiki \\
sistem demokrasi dengan melakukan penyuluhan cara \\
berdemokrasi yang baik, seperti memberi pelatihan dan \\
pendampingan tentang cara berdemokrasi yang santun. program \\
pengabdian kepada masyarakat masyarakat ini bertujuan \\
mengembangkan literasi demokrasi dalam pemilihan pemimpin \\
melalui proses pembelajaran. Program kegiatan masyarakat ini \\
menggunakan metode penyuluhan yang memiliki 3 tahapan. \\
Tahap 1 adalah identifikasi kondisi sekolah. Tahap 2 adalah \\
pelaksanaan program yang dirancang berdasarkan data di tahap 1. \\
Tahap 3 adalah evaluasi. Hasil pengabdian masyarakat ini \\
mengungkap bahwa sekolah sudah memberikan peluang bagi \\
siswa untuk berdemokrasi di lingkungan sekolah. Terbukti dengan \\
adanya kegiatan pemilihan ketua kelas, OSIS, dan sebagainya, \\
yang secara langsung dipilih oleh siswa-siswa. \\
\hline Development of Democratic Literacy in Leader Election through \\
the Learning Process \\
Abstract \\
\hline Democracy is a system of government where the highest power is in the \\
hands of the people. The world of education, including schools, has an \\
important role in helping to improve the democratic system by providing \\
counseling on good democratic methods, such as providing training and \\
mentoring on polite democracy. This community service program aims to \\
develop democratic literacy in selecting leaders through alearning process. \\
This community activity program uses the extension method which has 3 \\
stages. Stage 1 is the identification of school conditions. Stage 2 is the \\
implementation of programs designed based on data in stage 1 . Stage 3 is \\
evaluation. The results of this community service reveal that schools have \\
provided opportunities for students to democracy in the school \\
environment. This was proven by the selection of class leaders, student \\
council, and so on, which were directly elected by students. \\
\hline
\end{tabular}

Educivilia: Jurnal Pengabdian pada Masyarakat is licensed under a Creative Commons Attribution-Share Alike 4.0 International License. Copyright @ 2020 Universitas Djuanda. All Rights Reserved p-ISSN 2721-1541 | e-ISSN 2721-5113 


\section{PENDAHULUAN}

“Indonesia adalah negara demokrasi" itu kata-kata yang sering diperdengarkan akhir-akhir ini. Terutama menjelang pemilihan umum, pemilihan pemimpin baik di eksekutif maupun legislatif. Mulai dari tingkat nasional, provinsi, sampai daerah.

Pertanyaannya sekarang adalah apa yang dimaksud demokrasi dan mengapa sistem demokrasi yang dipilih oleh bangsa Indonesia dalam bernegara bukan sistem yang lain? Demokrasi adalah sebuah sistem pemerintahan dimana kekuasaan tertinggi berada di tangan rakyat.

Sesuai dengan rumusan pasal 1 ayat 2 UUD 1945 bahwa kedaulatan negara berada di tangan rakyat dan dijalankan menurut undang-undang.

Sementara menurut Lincoln dalam (Supardan, 2016) bahwa demokrasi adalah konsep pemerintahan yang berasal dari rakyat, oleh rakyat, dan untuk rakyat.

Berdasarkan definisi tersebut dapat disimpulkan bahwa sistem pemerintahan demokrasi adalah sebuah konsep pemerintahan dimana pemilihan pemimpin pemerintahan dipilakukan oleh rakyat karena rakyat yang memiliki kekuasaan tertinggi dalam sistem pemerintahan.

Dari sistem pemerintahan demokrasi tersebut, sejak tahun 2004, bangsa Indonesia memiliki kesempatan memilih pemimpin (presiden dan wakil presiden secara) secara langsung untuk menunjukan memang rakyat yang memiliki kekuasaan untuk memilih pemimpin secara langsung.

Konsep pemilihan secara langsung menjalar ke semua unit pemerintahan hingga sampai unit pemerintahan RT (rukun tetangga). Sehingga warga negara dapat mengenali, menganalisis, mendukung, hingga memilih pemerintahan yang mereka kehendaki.

Mengingat dampak baik dalam sistem pemilihan kepala pemerintahan secara langsung, pemerintah Indonesia melakukan pemilihan kepala daerah secara langsung secara serentak. Namun, pemilihan kepala pemerintahan secara langsung yang digadang-gadang oleh pemerintah, tidak selamanya berjalan mulus tetapi banyak kendala-kendala yang dihadapi. Sebagai contoh adanya ketidakdewasaan warga negara dalam berdemokrasi seperti melakukan kekerasan, menyebarkan berita-berita tidak benar 
(hoax), dan sebagainya untuk mendapatkan simpati rakyat sebagai pemilih. Oleh karena itu untuk menghindari hal-hal yang dapat menyederai demokrasi di Indonesia perlu partisipasi dari semua pihak, termasuk dunia pendidikan.

Dunia pendidikan termasuk sekolah memiliki peran penting dalam membantu memperbaiki sistem demokrasi dengan melakukan penyuluhan cara berdemokrasi yang baik, seperti memberi pelatihan dan pendampingan tentang cara berdemokrasi yang santun.

Demokrasi yang santun dapat ditunjukkan dengan cara menarik simpati pemilih, memberi ide atau gagasan yang benar, serta merangkul pesaing menjadi mitra kerja, dan sebagainya.

Seperti yang diutarakan oleh (Bessant, 2003) bahwa sekolah memiliki peranan penting dalam meningkatkan kesadaran dalam berdemokrasi kepada masyarakat termasuk para siswa dengan cara berpartisipasi dalam pemilihan pemimpin.

Hal senada diutarakan oleh (Sucianingsih, 2018) bahwa dalam proses membangkitkan kesadaran berdemokrasi tidak mudah karena memerlukan waktu panjang dan peran serta dari semua pihak.

Banyak contoh dari konflik yang terjadi merupakan contoh dari ketidakdewasaan berdemokrasi, antara lain konflik yang terjadi di Semarang, Toli-toli, dan masih banyak lagi konflik yang terjadi diberbagai daerah akibat penyelenggaraan pemilihan kepala pemerintahan secara langsung.

Ketidakdewasaan berdemokrasi tersebut menimbulkan berbagai macam dampak buruk seperti pengepungan dan pengerusakan kantor penyelenggara pemilihan umum (KPPU), pembakaran tempat-tempat umum, dan sebagainya. Hal tersebut harus dihentikan dan dicari jalan keluar yang tepat agar permasalahan tersebut tidak berlarut.

Banyak upaya yang sudah dilakukan untuk memberi pengetahuan tentang kedewasaan berpolitik, seperti seminar, pelatihan dan sebagainya, oleh berbagai pihak, pemerintah, dunia pendidikan, partai politik, dan sebagainya. Seperti yang dilangsir oleh (Dariyanto, 2015) bahwa partai politik berlomba-lomba mendirikan sekolah politik yang tujuan utama dari sekolah tersebut menciptakan pemimpin- 
pemimpin yang memiliki kedewasaan berdemokrasi.

Namun, upaya-upaya yang sudah dilakukan tampaknya belum maksimal. Dikarenakan masih banyak ditemukan prilaku-prilaku yang menunjukan ketidakdewasaan berdemokrasi yang berujung konflik.

Menumbuhkan nilai kepemimpinan berdemokrasi bukan hal mudah dan membutuhkan waktu yang panjang dan berkesinambungan. Menciptakan nilai kepemimpinan berdemokrasi tampaknya sulit terwujud hanya dengan pelatihan atau seminar 1-2 bulan melainkan harus ditanamkan dari usia belia.

Sekolah sebagai salah satu pilar pencetak generasi penerus bangsa yang berkualitas, memiliki peranan yang sangat penting untuk menanamkan dan menumbuhkan nilai-nilai kedewasaan berdemokrasi pada siswa sebagai generasi muda penerus bangsa dalam proses pembelajaran. Seperti yang kita ketahui siswa terutama yang duduk di tingkat menengah atas termasuk siswasiswa SMK merupakan warga negara yang telah memiliki hak konstitusi dalam pemilihan pemimpin secara demokrasi atau yang sering disebut dengan pemilih pemula.
Menurut (Nur Wardhani, 2018) dan (Triwardani \& Wiendijarti, 2016) pemilih pemula adalah warga negara yang telah berusia 17 tahun atau yang sudah atau pernah menikah sehingga pada diri mereka diberikan hak konstitusi dalam memilih pemimpin dalam pemilihan umum.

Siswa pada kelas XI atau XII memiliki adalah siswa yang memiliki usia 17. Oleh karena itu, siswa-siswa tersebut perlu diberi penyuluhan dalam proses demokrasi dalam memilih pemimpin. (Ackerman, 2018) menjelaskan bahwa nilai kepemimpinan merupakan kemahiran yang harus dikembangkan ddalam lingkungan pendidikan dalam menyongsong abad 21.

Berdasarkan penjelaskan tersebut dapat disimpulkan bahwa dunia pendidikan khususnya sekolah memiliki tanggung jawab dalam mencetak pemimpin yang dewasa, bijaksana, serta bertanggung jawab. Oleh karena itu literasi demokrasi dalam pemilihan pemimpin perlu diintegrasikan dalam proses pembelajaran, (Okoroji, Anyanwu, \& Ukpere, 2014). 
Hal senada juga dijelaskan oleh (Ziduli, Buka, \& Molepo, 2019) bahwa mengintegrasikan nilai-nilai demokrasi dalam pemilihan pemimpin dapat membantu meningkatkan kesadaran siswa dalam berpatisipasi pemilihan pemimpin.

SMK Negeri 7 Bandar Lampung yang terletak di jalan Pendidikan, Kelurahan Sukarame, Kecamatan Sukarame, Bandar Lampung adalah sekolah yang diresmikan pada tanggal 28 Agustus 2013. Itu berarti sekolah tersebut baru berjalan sekitar 7 tahun. Walaupun termasuk sekolah baru, sekolah ini tidak bisa dianggap sebelah mata karena sekolah tersebut sudah memiliki 9 program keahlian; teknik komputer dan jaringan, multimedia, teknik kendaraan ringan, teknik sepeda motor, farmasi, keperawatan, akuntansi, dan pemasaran.

Dengan banyaknya program keahlian yang dimiliki dapat membuktikan bahwa SMK Negeri 7 yang memiliki kualitas tinggi sebagai penyelenggara pendidikan formal. Saat ini SMK Negeri dipimpin oleh seorang kepala sekolah yang memiliki wawasasan pendidikan bernama Bapak Salahudin, S.T., M.Pd. Beliau dikenal juga sebagai pemerhati dan praktisi pendidikan. Sangat disayangkan bila sekolah sebagus SMK Negeri 7 Bandar Lampung hanya meluluskan siswasiswa yang pintar dalam keilmuan formal tanpa didukung dengan pengetahuan demokrasi sebagai bekal hidup bermasyarakat. Hal ini yang mengilhami tim abdimas ini memilih SMK Negeri 7 Bandar Lampung sebagai mitra abdimas karena ingin membantu para siswa memiliki kesadaran dalam pemilihan pemimpin berdasarkan asas demokrasi melalui pembelajaran.

Mengingat pentingnya menumbuhkan dan menciptakan nilai kepemimpinan yang berdasarkan kedewasaan berdemokrasi dalam kehidupan siswa, maka program pengabdian kepada masyarakat masyarakat ini bertujuan mengembangkan literasi demokrasi dalam pemilihan pemimpin melalui proses pembelajaran.

\section{METODE}

Program kegiatan masyarakat ini menggunakan metode penyuluhan yang memiliki 3 tahapan. Tahap 1 adalah identifikasi kondisi sekolah. Tahap 2 adalah pelaksanaan program yang dirancang berdasarkan data di tahap 1. Tahap 3 adalah evaluasi. Dalam 
tahap 1, kunjungan ke sekolah diadakan. Wawancara dengan kepala sekolah dan beberapa orang guru dilakukan untuk mendapatkan informasi mengenai profil sekolah secara umum dan kegiatan yang menjadi bagian gerakan literasi sekolah di SMK Negeri 7 Bandar Lampung. Dalam wawancara, sekolah juga mengemukakan apa yang diharapkan dari pengabdian masyarakat ini. Pada tahap kedua, kegiatan yang akan dilakukan dalam upaya mengembangkan gerakan literasi kepemimpinan dilakukan dengan mengkaji teori terkait dengan literasi kepemimpinan. Hal tersebut diperkuat dengan sedang diselenggarakannya pemilihan pimpinan siswa/osis yang dalakukan dengan cara pemilihan langsung.

\section{HASIL \& PEMBAHASAN}

SMKN 7 Bandar Lampung didirikan atas dasar kebutuhan pendidikan masyarakat untuk menciptakan para tenaga siap kerja. Proses pendidikan yang diselenggarakan di sekolah mempersiapkan lulusan yang memiliki kepakaran praktis disejumlah bidang. Tak hanya sekedar orientasi pada pemersiapan masa depan secara ketenagakerjaaan, SMKN 7 Bandar Lampung memiliki pembelajaran dasardasar yang dapat dipergunakan di masyarakat. Dasar iman dan taqwa merupakan dasar utama seorang siswa selama proses pembelajaran hingga lulus dan bermasyarakat. Dasar tersebut tentunya memberikan dampak langsung pada keahlian dan keterampilan sesuai pilihan siswa masing-masing.

Pemupukan kehidupan religiusitas tentunya diharapkan juga memengaruhi kehidupan social masyarakatnya, salah satunya hidup demokrasi.

Sebenarnya sekolah sudah memberikan peluang bagi siswa untuk berdemokrasi di lingkungan sekolah. Terbukti dengan adanya kegiatan pemilihan ketua kelas, OSIS, dan sebagainya, yang secara langsung dipilih oleh siswa-siswa. Namun, nampaknya peran sekolah dirasa kurang maksimal dalam kegiatan tersebut.

Mungkin pihak sekolah merasa acara tersebut hanya kegiatan siswa. Jadi, siswa yang harus melakukan secara penuh. Sebenarnya, dengan adanya acara pemilihan ketua OSIS atau kelas 
tersebut dapat dijadikan ajang menumbuhkan nilai kepemimpinan yang memiliki kedewasaan berdemokrasi yang nantinya bisa menjadi modal penting siswa dalam hdup bernegara.

Ada banyak hal yang dapat dilakukan pihak sekolah yang dapat dilakukan untuk membantu siswa menumbuhkan kedewasaan berdemokrasi; memberikan materi pelajaran yang bertemakan kepemimpinan seperti: an election, how to get voted, mendamping bagaimana mengemukakan ide dalam bentuk pidato sehingga khalayak tertarik, mendampingi membuat tim pemenangan serta pembagian tugas, membuat tim penyelenggara pemilihan pemimpin OSIS, pendampingan pembuatan winning speech, dan sebagainya.

Solusi yang diberikan adalah dengan memberikan penyuluhan untuk mengembangkan nilai-nilai demokrasi siswa dalam pemilihan pemimpin melalui pembelajaran berdasarkan program literasi sekolah tersebut. Program ini mencakup penyuluhan pengintegrasian nilai-nilai demokrasi dalam pemilihan pemimpin dalam bentuk materi ajar yang berbentuk teks atau pidato, dan sosialisai ide-ide. Dengan melakukan hal tesebut diharapkan memberi dampak positif bagi para siswa dalam mengembangkan pengetahuan tentang apa-apa saja yang harus dilakukan dalam proses pemilihan pemimpin berdasarkan asas demokrasi.

Adapun langkah-langkah yang akan dilakukan antara lain:

\section{Bagi guru:}

1. Meminta guru menganalisis potensi nilai kepemimpinan berdemokrasi dalam materi ajar (lihat gambar 1). Misalnya guru mengajar teks exposisi atau persuasi, maka guru dapat mengarahkan penjelasan materi tersebut kedalam tema "memilih pemimpin" atau cara "cara memenangkan pemilihan ketua osis."

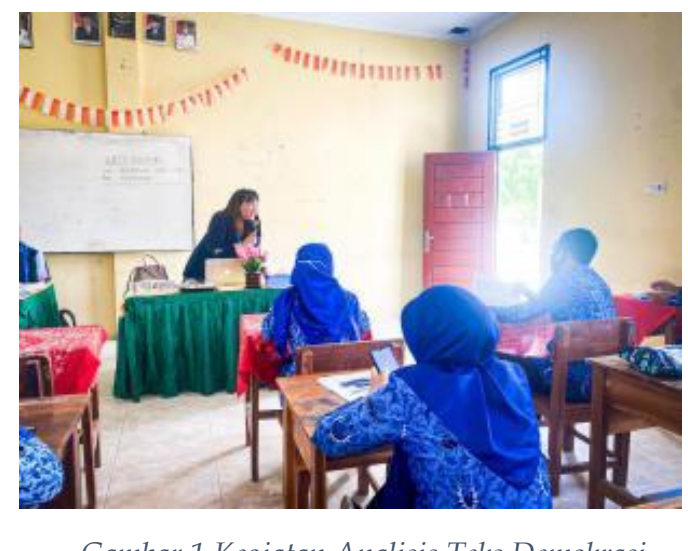

Gambar 1 Kegiatan Analisis Teks Demokrasi

2. Meminta siswa mengimajinaiskan dirinya ikut pemilhan ketua osis. 
Lalu, meminta siswa membuat alasan mengapa kamu memutuskan mengikuti pemilihan ketua osis? Program apa saja yang akan kamu lakukan? Siapa saja team pemenangan kamu? Buat teks yang menceritan mengapa khalayak perlu memilih kamu. Minta siswa tersbut membuat visi dan misi serta mengapa kamu layak jadi pemimpin (lihat gambar 2). Bayangkan kamu memenangkan pemilihan tersebut, lalu buat pidato kemenangan tersebut dan apa yang akan kamu lakukan terhadap kandidat lain yang kalah.

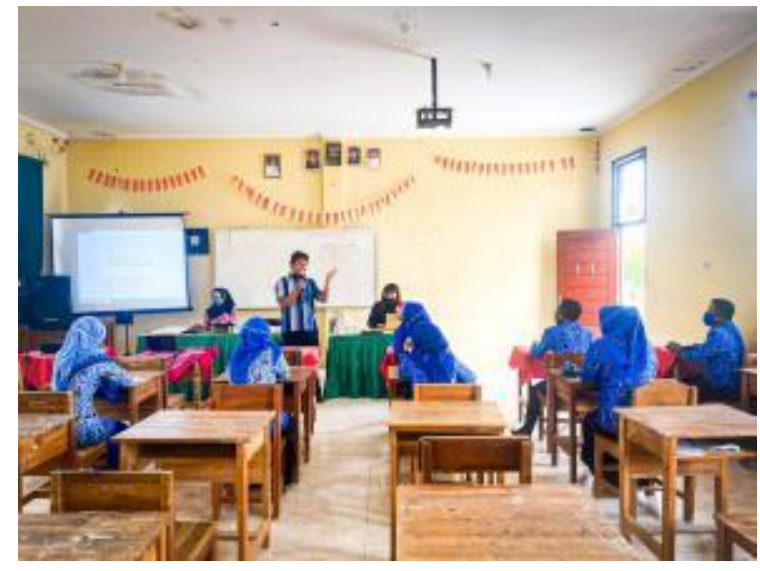

Gambar 2 Pemberian Arahan Simulasi Kampanye

3. Guru membimbing setiap tahap kegiatan tersebut (lihat gambar 3).

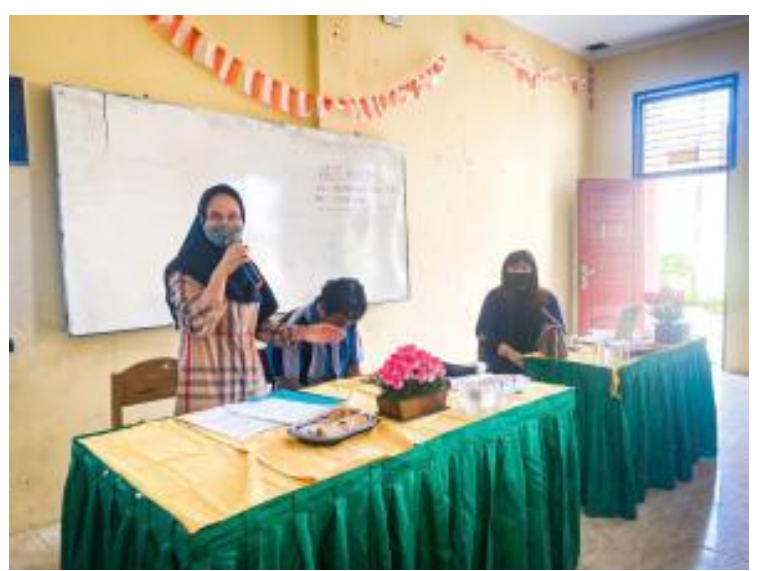

Gambar 3 Pembimbingan Proses Kampanye

\section{Bagi siswa:}

1. Meminta siswa mengungkapkan secara rinci tahapan-tahapan yang ada mulai dari alasan mengikuti pemilihan hingga melakukan pidato kemenangan (lihat gambar $4)$.

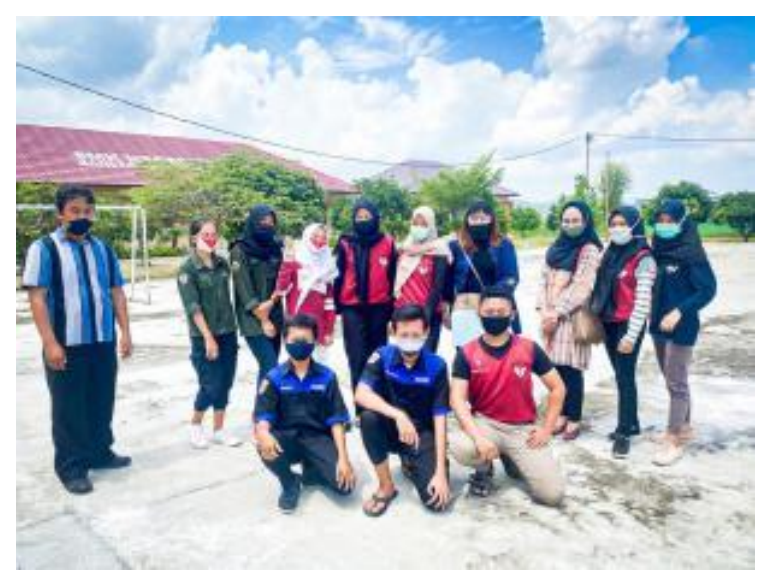

Gambar 4 Sesi Demonstrasi Pidato Kemenangan

\section{SIMPULAN}

Berdasarkan hasil kegiatan abdimas di SMK Negeri 7 Bandar Lampung yang berupa penyuluhan tentang integrasi nilai-nilai literasi demokrasi dalam pemilihan pemimpin dalam pembelajaran berjalan dengan lancar 
serta tanggapan baik dari pihak sekolah terhadap kegiatan tersebut. Kegiatan tersebut dianggap baik oleh sekolah terutama para guru karena penyuluhan tersebut memberi informasi tentang bagaimana menerapkan nilai-nilai demokrasi dalam pemilihan pemimpin sehingga dapat memperkaya khasanah pengetahuan dalam proses belajar mengajar terutama dalam pemilihan dan pengembangan materi ajar.

\section{UCAPAN TERIMA KASIH}

Ucapan terima kasih kepada Kepala Sekolah SMK Negeri 7 Bandar Lampung; Salahudin, S.T., M.Pd. serta para pendidik, para siswa, Ketua LPPM STKIP PGRI Bandar Lampung, serta semua pihak yang turut menyukseskan kegiatan pelatihan ini.

\section{DAFTAR PUSTAKA}

Ackerman, G. (2018). Brief Review of Fadel , C ., E Trilling , B . (2009). 21st Century Skills : Learning for Life in Our Times. San Francisco: JosseyBass . (April), 2010-2012.

Bessant, J. (2003). Youth Participation: A New Mode of Government. Policy Studies, 24(2-3), 87-100. https:/ / doi.org/10.1080/01442870 32000170984

Dariyanto, E. (2015). Saat Partai Berlomba-lomba Mendirikan Sekolah Politik. Retrieved from https:/ / news.detik.com/berita/d2961324/saat-partai-berlombalomba-mendirikan-sekolah-politik
Nur Wardhani, P. S. (2018). Partisipasi Politik Pemilih Pemula dalam Pemilihan Umum. Jupiis: Jurnal Pendidikan Ilmu-Ilmu Sosial, 10(1), 57.

https://doi.org/10.24114/jupiis.v1 0i1.8407

Okoroji, L. I., Anyanwu, O. J., \& Ukpere, W. I. (2014). Impact of leadership styles on teaching and learning process in Imo state. Mediterranean Journal of Social Sciences, 5(4), 180-193. https://doi.org/10.5901/mjss.2014 .v5n4p180

Sucianingsih, S. ani. (2018). Pemilih pemula dominasi pemilu 2019, apa dampaknya? Retrieved from https://nasional.kontan.co.id/new $\mathrm{s} /$ pemilih-pemula-dominasipemilu-2019-apa-dampaknya

Supardan, D. (2016). Sejaran dan Prospek Demokrasi. SOSIO DIDAKTIKA: Social Science Education Journal, 2(2), 125-135. https://doi.org/10.15408/sd.v2i2.2 811

Triwardani, R., \& Wiendijarti, I. (2016). Reception Analysis of Beginner Voter toward the Political Party Advertising of the Winning in the Election 2014. International Journal of Social Science and Humanity, 6(10), 779-784. https://doi.org/10.18178/ijssh.201 6.v6.748

Ziduli, M., Buka, A. M., \& Molepo, M. (2019). Leadership Styles of Secondary School Principals : South African Cases. 22(2018), 1-10. https://doi.org/10.31901/2456632 2.2019/23.1-3.911 